\title{
DIE QUELLEN DER YORK-SPIELE.
}

Obgleich die quellen der York Plays ${ }^{1}$ zu einem grossen teile bereits von fräulein Smith angegeben worden sind, so sehen wir uns dennoch veranlasst, eine neue untersuchung uber dieselben anzustellen, da wir in vielen punkten mit den ausfuhrungen jener dame nicht einverstanden sind. Wie aus den folgenden erörterungen zu ersehen sein wird, nimmt die herausgeberin der York Plays eine viel umfassendere quellenbentutzung seitens unseres dichters an, als wir unsererseits im stande sind, eine solche in den einzelnen spielen zu erkennen. Wir wollen in diesem teile der vorliegenden abhandlung versuchen, einen quellennachweis der York Plays im speziellen zu liefern und werden hierbei nicht nar die grösseren abschnitte der schriften angeben, auf deren grundlage die einzelnen spiele entstanden sind, sondern werden auch, so weit es uns möglich ist, alle jene weniger umfangreichen partien anfuhren, welche direkt aus den vorlagen hertbergenommen worden sind oder wenigstens enge anlehnung an dieselben zeigen. Die quellen der York Plays sind:

I. Die hieronymianische Bibelubersetznng i. e. Vulgata.

II. Einige pseudo-evangelien:

a) das pseudo-evangelium Matthaei;

b) das evangelium De Nativitate Mariae;

c) das pseudo-evangelium Nicodemi:

a) Gesta Pilati,

$\beta$ ) Descensus Christi ad Inferos;

d) der Transitus Mariae:

a) version $A$,

$\beta)$ version $B$.

1 York Plays etc. Edited by Lucy Toulmin Smith, Oxford 1885 $(=$ Y. P.).

Anglia, X. band. 
Spiel I (The Creation, and the Fall of Lucifer) beginnt mit einer in den mittelalterlichen mysterien tuber die schöpfung fast stereotyp gewordenen selbstbegrttssungsformel ${ }^{1}$ Gottes:

Ego sum Alpha et 0. vita via

Veritas primus et nouissimus,

einer verquickung von Apocal. I, 8:

Ego sum $\alpha$, et $\omega$, principium, et finis etc.

und Joh. XIV, 6:

Ego sum via, et veritas, et vita.

Der chor der engel singt nach seiner erschaffung:

Te deum laudamus te dominum confitemur (s. 2),

den berthmiten hymnus des bischofs Ambrosius von Mailand (starb 397).

Frl. Smith glaubt, dass unser dichter den fall Lucifer's und seiner genossen auf grund von Jud. I, 6:

Angelos vero, qui non servaverunt suum principatum, sed dere-

liquerunt suum domicilinm, in judicium magni diei, vinculis aeternis sub caligine reservavit

in seine darstellung aufgenommen habe. Dieser ansicht können wir jedoch nicht zustimmen. Nach unserer meinung ist dieser teil des spiels viel eher durch gewisse traditionelle ztige, welche unserem dichter von der gregorianischen engellehre noch bekannt waren, veranlasst worden. Dass dieses dogma in manchen kreisen des geistlichen standes noch bis weit in das mittelalter hinein bekannt und anerkannt war, zeigt das erste sttlck der Chester Plays ${ }^{2}$, in welchem nach der angabe Gregor's (Moralia lib. XXXII, 23.s. 1072 ed. Ben.) die neun klassen der engel aufgefthrt werden. Auch die folgende andentung der herausgeberin, dass die lobpreisungen Gottes seitens der getrenen engel auf grund von Job. XXXVIII, 7:

Cum me laudarent simul astra matina, et jubilarent omnes filii Dei in das uns vorliegende myster anfgenommen worden sein sollen, will nns nicht recht einleuchten. Unser dichter wurde sicher auch ohne kenntniss dieser stelle die allmacht des herrn durch die engel haben preisen lassen. Den abgefallenen engeln gegen-

1 In dem ersten spiele der Towneley Mysteries lautet dieselbe: Ego sum Alpha et 0, in dem der Chester Plays: Ego sum alpha et 0, primus ot ultimns, und in dem der Ludus Coventriae: Ego sum alpha et $\Omega$, principinm ot finis, also genau wie Apocal. I, 8. Dieser eingang findet sich auch in einem bei Devrient, Geschichte der deutschen Schauspielkunst, Leipzig 1848, s. 61 angefihrten myster: Ego sum alfa et omega.

${ }^{2}$ The Chester Plays: a Collection of Mysteries etc. Ed. by Th. Wright.

London. Printed for the Shakespeare Society 1843 (= Ch. P.). 
uber, welche entweder ihr trauriges geschick beweinen oder in ungebengtem trotze verharren, musste er auch solche gestalten auftreten lassen, die die wonne des himmels schildern und ihrem schöpfer fur ihr dasein danken.

Spiel II (The Creation, to the fifth day) ist eine freie und zum teil recht geschickte paraphrase der Gen. I, 6-25 erwähnten schöpfungsakte; bestimmte anklänge an den text der Vulgata sind indessen hierin nicht enthalten.

Ebenso frei von wörtlichen entlehnungen aus der heiligen schrift ist das dritte stlick, welches die schöpfung der menschen zum gegenstand hat. Die erschaffung des weibes wird hier vom herrn unmittelbar nach der Adam's bewirkt, während in der Vulgata zuvor das verbot Gottes betreffs des geniessens vom baume der erkenntniss (Gen. II, 16-17) berichtet wird. Nach der biblischen uberlieferung richtet sich die verheissung Gottes, durch welche der mensch zum herrn der erde erklärt wird, nur an Adam (Gen. I, 28-30), in unserem spiele dagegen ergeht dieselbe an das erste menschenpaar.

Im IV. spiele fuhrt der herr die ersten menschen in die gefilde des paradieses ein und gibt ihnen in recht hausbackener weise verhaltungsmassregeln. Das wichtige verbot, den baum der erkenntniss des guten und bösén zu meiden, spricht der dichter in enger anlehnung an die Vulgata aus (20,56-59):

The tree of good and yll,

What tyme you eates of thys

Thowe speydes thy self to spyll

Gen. II, 17:

And be brought owte of blysse:

In quocumque enim die comederis ex eo, morte morieris.

Die verfuhrung der Eva im fiunften stlucke unserer sammlung wird in ziemlich enger anlehnung an Gen. III, 1-15 behandelt. Wörtliche ubereinstimmung mit dem biblischen texte zeigen die verse $24,71-72$ :

Ay! goddis shalle ye be!

Gen. III, 5:

of ille and gode to have knawyng:

Et eritis sient dii, scientes bonım et malum und $27,155,158-159$ :

And on thy wombe pan shall pou glyde

And erthe it shalle thy sustynaunce be

Gen. III, 14:

to ete \& drynke : 
Super pectus tuum gradieris et terram comedes.

Die bedenken, die in diesem myster Eva gegen die verfuhrungsktinste Satan's vorbringt, sind in der tat recht schwach, und bei Adam ist anch nicht eine spur von irgend einem kampfe zwischen pflichtgebot und verlangen zu bemerken.

Spiel VI schildert die reue der aus eden vertriebenen stunder in naturalistischer weise. Wrahrend Eva nach der darstellung der Vulgata ihre strafe unmittelbar nach dem falle ans dem munde Gottes erfăhrt, wird ihr dieselbe in unserem stucke erst nach der vertreibung aus dem paradiese durch einen engel verktundigt $(31,71-74)$ :

Thy barnes to bere with mekill wa pis warne $I$ pe

Buxom shalle pou and othir ma to man ay be:

Gen. III, 16:

In dolore paries filios, et sub viri potestate eris.

Das nächste myster (Sacrificium Cayme and Abell) beruht seinem inhalte nach auf Gen. IV, 8-15 und nähert sich in einzelnen partien stark dem wortlante der vorlage. Kain's worte 38,89 :

Quis non sum custos fratris mei

sind ans Gen. IV, 9 entlehnt:

Num custos fratris mei sum ego?

Desgleichen stimmt fast wortlich tberein 38, 99-101:

What hast pou done? beholde and heere,

be voice of his bloode cryeth vengeaunce

Fro erthe to heuen -

mit Gen. IV, 10:

Quod focisti? vox sanguinis fratris tui clamat ad me de torra, ferner 39, 121-126:

Fro pe shalle I be bidde in hye, bou castis me, lorde, oute of my kyth

In lande.

Both here and there oute-caste am I,

For ilke a man pat metis me with,

They wille slee me -

mit Gen. IV, 14;

Ecce ejicis me hodie a facie terrae, et a facie tua abscondar, et ero vagus et profingus in terra: omnis igitur, qui invenerit me, occidet me

und 39, 128-130: 
Nay, Cayme nouzt soo, haue pou no drede, Who pat pe slees shalle ponnysshed be Sevene sithis -

mit Gen. IV, 15:

Nequaquam ita fiet: sed omnis, qui occiderit Cain, septuplum punietur.

Die ermordung Abel's ist in dem uns vorliegenden spiele nicht enthalten, da gerade diese partie der handschrift (zwei blätter) verloren gegangen ist. - Die gestalt des groben, ungeschlachten Kain gewinnt für uns insofern ein gewisses kulturgeschichtliches interesse, als wir in ihr einen vertreter des englischen banernstandes jener zeit erblicken können. In dem entsprechenden stlicke der Towneley-sammlung wird Kain ebenfalls als grober Yorkshire-bauer dargestellt; aber dort gehen die rohheiten desselben oft so in's gemeine und obscöne, dass die derbheiten des helden in unserem myster dagegen noch zahm zu nennen sind.

Spiel VIII (The building of the Ark) zeigt keine wesentlichen abweichungen von der darstellung der Vulgata (Gen. VI, 5-VII, 5). Die grössenverhältnisse der arche sind, dem biblischen texte entsprechend, beibehalten $(42,81-83)$ :

III $\mathrm{C}$ cubyttis it sall be long, And fyfty brode, all for thy blys, be highte of thyrty cubittis strong:

Gen. XIV, 15:

Trecentorum cubitorum erit longitudo arcse, quinquaginta cubitorum latitudo, et triginta cubitorum altitudo illius.

Den bau dieses fahrzeuges musste der dichter mit einer gewissen breite beschreiben, um den schiffsbauern, die dieses stuck aufzuftuhren hatten, gelegenheit $z \mathfrak{u}$ geben, ihre handwerkstätigkeit zur schau zu tragen, eine handwerkstätigkeit, die fur das englische volk von ganz besonderem interesse war.

Das folgende myster (Noah and his wife, the Flood and its waning) berthrt sich nur sehr wenig mit der therlieferung der Vulgata (Gen. V, 28-32; VII, 6-VIII, 18; IX, 11-14). Die verse $46,31-32$ :

'Loo', he saide, 'pis ilke is he

That shalle be comforte to mankynne',

welche durch die interpunktion eigens als citat angedeutet sind, beziehen sich auf Gen. V, 29: 
Iste consolabitur nos ab operibus et laboribus manuum nostrarum, in terra etc.

und 54, 283:

Arcum ponam in nubibus

ist wortlich aus Gen. IX, 13 entlehnt. Ein ausspruch Noah's, wie 54,301-302, dass die welt am ende der tage durch feuer untergehen werde, findet sich in der Genesis nicht; derselbe ist vom dichter wol auf grund von 2. Thess. I, 8, 2. Petr. III, 90, 1. Cor. III, 13-15 aufgenommen worden. Die scene, welche frau Noah vor dem eintritt in die arche heraufbeschwört, gewährt uns ein teilweise ergötzliches bild des damaligen niederen burgerstandes in England. Wie in unserem, so setzt sich auch in den entsprechenden stticken der Towneley-1 und Chestersammlung Noah's gemahlin der einschiffung auf's hartnäckigste entgegen; in dem Coventry-myster aber ist dieselbe sofort bereit, ihre zuflucht in das rettende fahrzeng zu nehmen.

Spiel X (Abraham's sacrifice of Isaac) schliesst sich in den einzelheiten genan an den gang der Vulgata an; so wird das alter Abraham's bei der geburt Isaak's, wie in Gen. XXI, 5, auf hundert jahre angegeben $(56,5-6)$; die erzählung des patriarchen von der unfruchtbarkeit Sarah's und der geburt Ismael's $(57,29-40)$ entspricht dem inhalte nach vollkommen Gen. XVI, 1-3, 15; ebenso sind vom dichter auf grund von Gen. XXII, 3, 5 zwei famuli eingefthrt worden (s. 59-60), welche jhren herrn als eseltreiber bis vor die opferstätte begleiten. Das gespräch aber zwischen Abraham und seinem sohne Isaak in der, zweiten scene ist, bis anf die verse 61, 161-168:

Fadir, I see here woode and fyre,

Bot wherof sall oure offerand be,

welche sich Gen. XXII, 7:

Ecce, inquit, ignis et ligns: ubi est victima holocsusti

năhern, durchaus eigene erfindung des verfassers. Anlehnung an den wortlant der Vulgata zeigen die verse 58,69-74:

Isask, pi sone, pat is the dere,

Whom pou loues ouer alle thyng,

To pe lande of Vyssyon wende in feere,

And there of hym pou make offering.

1 The Towneley Mysteries. London 1836 (in den Publications of the Surtees Society, hersusgegeben von Hunter) [= T. M.]. 
I salle pe shewe fulle sone,

The stede of sacrifice:

Gen. XXII, 2:

Tolle filium tuum unigenitum, quem diligis, Isaac, et vade in terram visionis, atque ibi offeres eum in holocaustum super unum montium, quem monstravero tibi

und $67,347-348$ :

For in youre seede all mon be bliste,

That ther bese borne be nyght or day:

Gen. XXII, 18:

Et benedicentur in semine tuo omnes gentes terrae.

Eine abweichung von der darstellung der Vulgata hat sich der dichter insofern erlaubt, als hier Abraham die tochter Bethuel's, Rebekka, zur gemahlin seines sohnes bestimmt, während diese nach Gen. XXIV, 15 erst von Elieser am brunnen gefunden wird.

Das folgende myster (The departure of the Israelites from Egypt, the ten plagues, and the passage of the Red Sea) gibt in gedrängter weise den inhalt von Exod. I-XIV wider. Die beruhrungen mit diesem teile der heiligen schrift sind aber so allgemeiner natur, und die einzelnen tuberlieferungen sind oft so willkürlich geändert, dass wir kaum annehmen können, der dichter habe bei abfassung dieses stuckes den text der Vulgata vor sich gehabt. Die einzige und vielleicht nur zufällige tbereinstimmung findet sich in den worten 72,61-62:

For with qwantise we sall pam qwelle,

bat pei sall no farrar sprede:

Exod. I, 10:

Venite, sapienter opprimanus eum (sc. populum), ne forte multiplicetur.

Nicht biblischen ursprungs, sondern wahrscheinlich erfindung unseres autors ist die angahe, dass sich die Israeliten in einem zeitraume von 400 jahren von 70 auf 300,000 mann vermehrt hätten (71, 49-57). Das Exod. IV, 6 berichtete wunder:

Mitte manum tuam in sinum tuum. Quam cum misisset in sinum, protulit leprosam instar nivis,

welches Moses vor könig Pharao als beweis seiner göttlichen sendung ausfuhren soll, ist in diesem spiele falsch widergegeben $77,153-154$ :

Hyde thy hande in thy barme, And serpent it sall be like. 

be dewe to fall fro heuen so ferre,

For than the erthe sall sprede and sprynge

A seede pat vs sall saue

spielt der dichter wol auf die segnung Jakob's durch Isaak an, Gen. XXVIl, 28:

Det tibi Deus de rore caeli, et de pinguedine terrae abundantiam frumenti et vini.

Die weissagung:

Propter hoc dabit dominus ipse vobis signum.

Ecce uirgo concipiet, et pariet filium \&c. (s. 95)

ist wörtlich aus Isa. VII, 14 entnommen und wird vom dichter auf folgende weise übersetzt $(95,57-64)$ :

Loo he sais pus, god sall gyffe

Hereof a syngne to see

Tille all pat lely lyffe,

And pis pare sygne salbe.

Loo! he sais a maydenmon

Ilere on this molde mankynde omell,

Ful clere consayue and bere a sonne,

And neven his name Emanuell.

Die nächsten verse $95,65-70$ :

His kyngdom pat euer is begonne,

Sall never sese, but dure and dwell;

On dauid sege pore sall he wonne,

His domes to deme and trueth to telle.

Zelus domini faciet hoc \&c.

He says, luffe of oure I orde,

All pis sall ordan panne

beziehen sich auf Isa. IX, 7:

Multiplicabitur ejus imperium, et pacis non erit finis; super solium David, et semper regnum ejus sedebit; zelus Domini exercituum faciet loe,

und die worte $(96,75-79)$ :

Egredietur virga de Jesse,

A wande sall brede of Jesse boure;

And of pis same also sais hee,

Vpponne pat wande sall springe a floure,

Wheron pe haly gast sall be

zeigen starke anlehnung an Isa. XI, 1-2:

Et egredietur virga de radice Jesse, (et flos de radice ejus ascendet)

Et requiescet super eum spiritus Domini.

Eine der eben angefthitten gleiche oder ähnliche weissagung bei Joel, von der der antior 96, 85-86 spricht, ist in 
der schrift dieses propheten nicht vorhanden. Diese abermalige falsche angabe zeigt uns, dass der dichter bei abfassung seiner spiele die in die darstellung aufgenommenen oder in derselben nur angedeuteten citate nicht immer auf ihre richtigkeit prufte, sondern dass er sich sehr hănfig bloss auf sein gedächtniss verliess. Die verse $96,89-91$ :

be maiden of Israell all newe

He sais, sall bere one and forthe brynge,

Als pe lelly floure full faire of hewe

sind eine etwas freie tbersetzung von Hos. XIV, 6 :

Ero quasi ros, Israel germinabit sicut lilium,

und in den worten $(97,113-118)$ :

He sais pe septer sall noght passe

Fra Iuda lande of Israell,

Or he comme pat god ordand has

To be sente feendis force to fell.

Hym sall alle folke abyde,

And stand vnto'his steuen

erkennen wir eine solche von Gen. XLIX, 10:

Non auferetur sceptrum de Juda, et dux de fenore ejus, donec veniat qui mittendus est, et ipse erit expectatio gentium.

Von den beiden folgenden citaten (s. 97) ist das eine:

Ecce mitto angelum meum ante faciem tuam qui preparabit viam tuam ante te

wörtlich aus Marc. I, 2 und das andere:

Ego quidem bsptizo in aqus ros antem

Baptizsbimini spiritu sancto

mit einer verderbniss des textes, die offenbar anf ein versehen oder auf ungentlgende kenntniss der lateinischen sprache seitens des abschreibers zurtlckzufthren ist, aus Matth. III, 11:

Ego quidem baptizo vos in aqua in poenitentiam: ipse vos baptizabit in Spiritu sancto, et igni

entlehnt. Wir konnen die form baptizabimini ohne bedenken durch (ipse vos) baptizabit ersetzen, zumal auch nach der thersetzung dieses citats $(97,129-132)$ :

'Eftir me sall come nowe

A man of myghtist mast,

And sall baptis zowe

In the high haly gast'

eine passivische form hier gar keinen sinn hat.

Die vom dichter ausdrttcklich als ein citat aus Lucas bezeichneten verse $98,135-140$ : 
'Fro God in heuen es sent', sais he,

'An aungell is named Gabriell

To Nazareth in Galale,

Where pan a mayden mylde gon dwell,

bat with Joseph suld wedded be.

Hir name is Marie'

beziehen sich auf Luc. I, 26-27:

In mense autem sexto, missus est Angelus Gabriel a Deo in civitatem Galilaeae, cui nomen Nazareth;

Ad virginem desponsatam viro, cui nomen est Joseph, de domo David, et nomen virginis Mariae.

Nach dem prologe hebt das eigentliche sttick mit engelsgesang an. Die begrïssung der heiligen jungfrau seitens des engels 98, 145-148:

Hayle! Marie! full of grace and blysse,

Oure lord god is with pe,

And has chosen pe for his,

of all women blist mot pou be

schliesst sich eng an Luc. I, 28 an:

Ave gratia plena: Dominus tecum: Benedicta tu in mulieribus und ebenso die verktindigung der geburt Christi 98, 153-99,168:

Ne drede pe noght, pou mylde marie,

For nothyng pat may befalle,

For pou has fun soueranly

At god a grace ouer othir all.

In chastite of thy bodyo

Consayue and bere a childe pou sall,

This bodword brynge I pe, forthy

His name Jesu sall pou calle.

Mekill of myght pan sall he bee,

He sall be God and called God sonne.

Danid sege, his fadir free,

Sall God hym giffe to sytte vppon;

Als kyng for eucr regne sall hee,

In Jacob house ay for to wonne.

Of his kyngdome and dignite

Shall noo man erthly knaw ne con.

an Lucas I, 30-33:

Ne timeas Maria, invenisti eniru gratiam apud Deum:

Ecce concipies in utero, et paries filium, et vocabis nomen ejus Jesum.

Hic erit magnus, et Filius Altissimi vocabitur, et dabit illi Dominus Deus sedem David patris ejas: et regnabit in domo Jacob in aeternum,

Et regni ejus non erit finis. 
Auch die folgenden worte des engels 99, 177-184:

The Halygast in pe sall lighte,

Hegh vertue sall to pe holde,

The holy birthe of the so bright,

God sonne he sall be calde.

Loo, Elyzabeth, pi cosyne, ne myght

In elde consayue a childe for alde,

bis is pe sexte moneth full ryght,

To hir pat baran has ben talde

sind eine recht getreue thersetzung von Luc. I, 35-36:

Spiritus sanctus superveniet in te, et virtus Altissimi obumbrabit

tibi. Ideoque et quod nascetur ex te Sanctum, vocabitur Filins Dei.

Et ecce Elisabeth cognata tua, et ipsa concepit in senectute sua:

et hic mensis sextus est illi, quae vocatur sterilis.

Von dem grusse Elisabeth's an Maria beruhen die verse 100, 205-208:

Blissid be pou snely

Of all women in feere,

And pe frute of thy body

Be blissid ferre and nere

anf Lucas I, 42:

Benedicta tu inter mulieres, et benedictus fructus ventris tui and die worte 100, 213-216:

Sone als pe voyce of pine haylsing

Moght myn neres entre and be,

$b_{e}$ childe in my wombe so yenge,

Makes grete myrthe vito pe

auf Luceas I, 44:

Ecce enim ut facts est vox salutionis tuse in auribus meis, exultarit in gaudio infans in utero meo.

Am schlusse dieses spiels singt Maria den berthmten lobgesang $(101,237-240)$ :

My saule sall louying ma

Vnto pat lorde so lele,

And my gast make ioje alswa

In god pat es my hele

Luc. I, 46-47:

Magnificat anima mea Dominum: Et exultavit spiritus meus in Deo salutari meo.

Spiel XIII (Joseph's trouble about Mary) beruht fast ganzlich auf apokrypher grundlage, namentlich auf dem pseudoevangelium Matth.1 $X-X I$ und zum teil auf dem psendo-

1 Pseudo-Matthaei Evangelium in Tischendorf's Evangelia Apocrypha, Lipsiae 1853, s. 50-105. 
evangelium de Nativitate Mariae 1 VII-VIII. Aus dem kindheitsevangelium hat der verfasser den stoff fur einen teil von Joseph's monolog geschöpft, in welchem dieser die wunderbare geschichte seiner verheiratung mit Maria berichtet. Die ansicht der herausgeberin, dass hierbei auch noch das protevangelium Jac. ${ }^{2}$ IX als direkte vorlage gedient habe, scheint uns wenig treffend zu sein, da in dieser schrift gerade das wunder, durch welches Joseph zum gemahl der heiligen jungfrau bestimmt wird, anders als in unserem spiele berichtet wird. Nach der darstellung dieses apokryphen evangeliums entsteigt dem stabe Joseph's eine taube, während nach der des uns vorliegenden mysters das dtirre reis zu grtinen und zu blthen beginnt. ${ }^{3}$ Im ubrigen teile dieses stiuckes folgt der dichter der darstellung des pseudo-evang. Matth., lehnt sich aber nur äusserst wenig an den wortlaut seiner vorlage an; die relativ grösste tubereinstimmung in dieser beziehung zeigen noch die verse 106, 123-137:
I. Puella. Na, here come noman in pere wanes, And pat euere witnesse will we, Saue an Aungell ilke a day anes, With bodily foode hir fedde has he, 0 thir come nane.
Wharfore we ne wate how it shulde be, But thurgh pe haly gaste allone.
For trewly we trowe pis,
is grace with hir is gone,
For sho wroght neuere no mys, we witnesse euere ilkane.
Jos. Janne se I wele youre menyng is, be Aungell has made hir with childe. Nay, som man in aungellis liknesse With somkyn gawde has hir begiled.

mit pseudo-evang. Matth. X:

Nos scimus quoniam vir non tetigit eam; nos sumus testes. Quotidie angeli dei cum ea loguuntur; quotidie de mana domini

${ }^{2}$ Evangelium de Nativitate Mariae bei Tischendorf s. 106-114.

3 Protevangelium Jacobi bei 'Tischendorf s. 1-49.

3 Beide fassungen sind vereinigt im Cursor mundi (Cotton.-manuskript) 10773-10776:

Nedings forth his wand he broght;

ban alson sum it was sene

Wit lef and flur pai fand it grene,

A duu pat was fra heuen send

bare lighted dun, and paron lend;

Die verbreitetste ist indessen die, welche in unserem spiele erscheint. 
escam accepit. Nam si suspicionem nostram tibi vis ut pandamus, istam gravidam nemo fecit nisi angelus domini. Nescimus quomodo fieri possit ut sit peccstum aliquod in ea. Joseph dixit nt quid me seducitis ut credam vobis quoniam angelus domini impraegnavit ean? Potest enim fieri nt quis se finxerit angelum domini et decoperits eam.

Eine abweichung unseres mysters von der Vulgata zeigt sich darin, dass hier ein engel den alten Joseph veranlasst, mit seinem weibe von Nazareth nach Bethlehem aufzubrechen, während diese reise nach Luc. II, $1-5$ infolge der vom kaiser Augustus ausgeschriobenen schätzung unternommen wird.

Das nächste sttlck (The Journey to Bethlehem; the birth of Jesus) ist eine etwas weitschweifige ansfthrung von Lnc. II, 5-7. Die weissagung $116,139-140$ :

\section{He saide oure sanyoure shall be sene betwene bestis lye,}

welche der dichter ansdrticklich als eine solche ans Habakuk bezeichnet $(116,136-138)$, ist unseres wissens weder in der schrift dieses propheten noch in irgend einer andern der Vulgata enthalten. Aber merkwtirdigerweise findet sich genau dieselbe prophezeinng and unter ganz derselben bezeichnung als citat aus Habakuk in dem traktate De nativitate Salvatoris der Historia scholastica ${ }^{1}$ des gelehrten französischen priesters Petrus Comestor:

Et illud Habacuc: In medio duorum animalium cognosceris.

Ist es schon an sich anffallend, dass sowol in unserem spiele als auch bei Comestor eine stelle, welche jedenfalls in der heiligen schrift gar nicht existiert, ein und demselben antór beigelegt wird, so ist es kanm als blosser zufall za betrachten, wenn diesem ausspruche widerum in beiden werken eine und dieselbe prophezeinng, næmlich Jes. I, 3, unmittelbar vorangeht. Ob hier nun eine entlehnung seitens unseres dichters aus der Historia scholastica (zwischen 1169-1175 entstanden) oder einer von deren quellen vorliegt, wagen wir aus mangel an anderen beweisen nicht zu entscheiden. Wenn dies aber der fall ist, so ist es um so auffalliger, dass wir auch in den tbrigen sttlcken unserer sammlung keine beziehung $\mathrm{zu}$ jenem werke auffinden können.

1 Historia scholastica ernditissimi viri magistri Petri Comestoris in Migne's Patrologia, bd. 198. 
Spiel XV (The Angels and the Shepherds), welches sich durch die drastische lebendigkeit der auftretenden schäfer vorteilhaft vor den übrigen mysterien auszeichnet, zeigt nur sehr wenig berihhrungspunkte mit dem biblischen texte (Luc. II, 8-16). Das erscheinen der himmlischen heerschaaren wird durch die buhnenweisung 'Vision of Angels in the sky' bezeugt; von dem gesange derselben, der vermutlich auf Luc. II, 10-11, 14 gegrundet war, ist uns indessen der text nicht tberliefert. Antibiblisch ist die verteilung von geschenken seitens der hirten an den heiland. Diese abweichung von der Vulgata ist gewiss auch hier auf eine beeinflussung des autors durch die darsteller (hier die 'Chaundelers') zuriickzufuhren.

Das folgende myster (The coming of the three Kings to Herod; the Adoration) ist eine selbständige, freie gestaltung des neutestamentlichen stoffes (Matth. II, 1-12). Die dem dritten rex in den mund gelegte prophezeiung $132,161-165$ :
Sir, Isaie sais a mayden zenge
Shall bere a sone amonge Ebrewes, bat of all contrees shall be kyng, And gouerne all pat on erthe grewes;
Emanuell sbal be his name

bezieht sich auf Isa. VII, 14:

Emmanuel,

Ecce! virgo concipiet, et pariet filium, et vocabitur nomen ejus und mit der nächsten weissagung 132, 171-172:

lat a mayden of lsraell, sais he,

Shall bere one like to pe lely floure,

welche der erste rex ausdritcklich als eine solche aus Hos. citiert, deutet der verfasser anf Hos. XIV, 6 hin:

Ero quasi ros, Israël germinabit sicut lilium.

Die spiele XVIII-XI hahen ihren gegenstand zwar der Vulgata entlehnt, zeigen aber in der einzelausfuhrung solche unabhängigkeit von ihren quellen, dass wir sie als volles eigentum des dichters anerkennen míssen. Nirgends können wir direkte herubernahme aus den betreffenden partien der Vulgata oder auch nur engere anlehnungen an den wortlaut derselben nachweisen. Auch apokryphe zuge, die namentlich in den mittelalterlichen legenden tiber die geschichte der kindheit Christi sehr beliebt waren, sind in diesen vier mysterien nicht zu finden. Das sujet zu spiel XVIII (The Flight into Egypt) ist aus Matth. II, 13-15 entlebnt, das zu spiel XIX 
(The Massacre of the Innocents) ans Matth. II, 16, das zu spiel XX (Christ with the Doctors in the Temple) aus Luc. II, 41-51 und das zu spiel XXI (The Baptism of Jesus) ans Matth. III, 1-3, 13-17. Das zwanzigste myster stimmt tbrigens in den versen 73-288 mit dem grössten teile von spiel XVIII der Towneley-sammlung (von vers 49 bis zum schluss) therein.

$\mathrm{Zu}$ dem spiele The Temptalion of Jesus gibt fränlein Smith die evangelien Matthaei nnd Lucas als vorlagen an. Die versuchungsgeschichte Christi wird bei beiden evangelisten allerdings ziemlich tbereinstimmend dargestellt, aber aus verschiedenen partien unseres mysters, welche sich dem wortlaute nach enger an Matthaeus als an Lucas anlehnen, ersehen wir, dass dem dichter bei abfassung dieses sttickes jedenfalls nur das Matth.-evang. als vorlage gedient hat. Die verse 180, 74-78:

For wrytyn it is, whoso vndirstande,

A man lyvis noght in mayne and mode with brede allone.

But goddis wordis are gostly fode to men ilkone

beziehen sich auf Matth. IV, 4:

Scriptum est: Non in solo pane vivit homo, sed in omni verbo, quod procedit de ore Dei, und die worte 181, 103-108:

For it is wretyn, as wele is kende;

How God schall aungellis to pe sende, And they sohall kepe pe in per hande wherso pou gose, bat pou schall on no stones descende to hurte pi tose

lehnen sich immer noch etwas enger an Matth. IV, 6:

Scriptum est enim: Quia angelis suis mandavit de te, et in manibus tollent te, ne forte offendas ad lapidem pedem tuum

als an Luc. IV, 10-11 an:

Scriptum est enim quod Angelis snis mandavit de te, ut conservent to:

Et quis in manibus tollent te, ne forte offendas ad lapidem pedem tuum

Ebenso entsprechen die worte 183, 164-168:

For wretyn it is, who right can rede,

Thy lord God pe aught to dede and honoure ay;

And serue hym in worde and dede, both nyzt and day, 
welche Christus nach der endgiltigen zuruckweisung Satan's ausruft, gewiss mehr Matth. IV, 10:

Scriptum est enim: Dominum Deum tuum adorabis, et illi soli servies als Luc. IV, 12:

Dictum est: Non tentabis Dominum Deum tuum.

In dem XXIII. myster (The Transfiguration) nimmt frl. Smith eine benutzung aller vier evangelien seitens unseres dichters an. Ausser einer stelle, welche aus Joh. entlehnt ist, ist dieses sttlck aber sicher bloss auf grund des Matth.-evangeliums entstanden. Für die verse 186, 27-42 zieht diese dame Luc. II, 18-22 als quelle heran; aber gerade in dieser partie haben wir zwei beweise, dass der dichter hierbei nur Matth. XVI benutzt hat. Während die beiden zeilen 186, 27-28:

\section{(I saide,) quem dicunt homines} esse filinm hominis

wort fur wort mit Matth. XVI, 13 ubereinstimmen und durch unseren autor auch eine diesem citate völlig entsprechende ubersetzung erfahren $186,29-30$ :

I askid zow wham pe pepill chase

To be mannys sone, withouten mys,

lauten dieselben bei Luc. (IX, 18):

Quem me dicunt esse turbae.

Ferner können die worte des herrn 186, 39-40:

Bot of thy selffe pat had noght powe,

My Fadir hadde pat grace begonne

nur auf grund von Matth. XVI, 17:

(Beatus es Simon Bar-Jonas): quia caro, et sanguis non relevavit tibi, sed Pater meus

in dieses stluck aufgenommen worden sein, da dieselben nur hier, sonst aber an keiner anlleren stelle der evangelien zu finden sind. Zur bekriiftigung unserer behauptung, dass der dichter bei abfassung dieses spieles auf Matthaeus und nicht auf Lucas zurtickgegangen sei, können wir auch die verse 188, 97-98 herbeiziehen:

His clothyng is white as snowe,

His face schynes as pe sonne,

welche fast wörtlich aus Matth. XVI, 2:

Et resplenduit facies ejus sicut sol: vestimenta antem ejus facta sunt alba sicut nix

ubertragen sind; im Luc.-evangelium lautet die entsprechende stelle (IX, 29): 
Et facta est, dum oraret, species vultus ejus alters: et vestitus ejus albus et refulgens.

In Petrus' worten 190, 149-156:

Here is full faire dwellyng for vs,

A lykand place in for to lende,

A! lord, late vs no forther trus,

For we will make with herte and hende

A taburnakill vnto be

Belyue, and pon will bide,

One schall to Moyses be,

And to Ely the thirde

ist eine anlehnung an Matth. XVII, 4 unverkennbar:

Domine, bonum est nos hic esse: si vis, faciamus hic tria tabernacula, tibi unum, Moysi unum, et Elise unum.

Eine thbereinstimmung mit dem Joh.-evangelium zeigt sich in den versen $186,17-20$ :

'Shewe v8 thy ffadir', pus saide ze then,

'Pat suffice vs withouten more';

- I saide to zou and to all men,

Joh. XIV, 8-9:

'Who seis me, seis my fadyr pore':

Domine, ostende nobis Patrem, et sufficit nobis.

Qui videt me, videt et Patrem.

Der gegenstand des nächsten mysters (The Woman taken in Adultery. The raising of Lazarus) ist dem Joh.-evangelium VIII, $3-11$ und XI, 1-44 entlebnt. Von dem gespräche zwischen Christus und der ehebrecherin schliessen sich besonders eng an den biblischen text an die verse 195, 63-69:

Jesus. Woman! wher are po wighte men went

That kenely here accused pe?

Who hase pe dampned, toke pon entent?

Mul. Lord! no man has dampned me.

Jesus. And for me schall pou nozt be schent;

Of all thy mys I make pe free,

Loke pou nomore to synne assentte:

Joh. VIII, 10-11:

Mulier, ubi sunt, qui te accusabant? nemo te condemnavit?

Quso dixit: Nemo, Domine. Dixit autem Jesus: Nec ego te condemnabo: Vade, et jam amplius noli peccare.

Der zweite teil dieses sttlckes, die anferweckung des Lazarus, zeigt eine ansserordentliche fulle von anlehnungen an die vorlage. 196, 103-104, 107-197, 112:

Nunc. He whom pon lones full wele alway

Es seke, and like, lord, for to dye. 
Jesus. I saie zou pat sekeness

Is nozt onlye to dede,

But joie of goddis gudnesse

Schal be schewed in pat stede.

And goddis sone schall be glorified

By pat sekenesse and signes feere

entspricht Joh. XI, 3-4:

Domine, ecce quem amas infirmatur,

Audiens autem Jesus dixit eis: Infirmitas haec non est ad mortem, sed pro gloria Dei, ut glorificetur Filius Dei per eam.

$197,115-128,131-139 ; 198,143,146$ :

Jesus. We will go soiourne here beside

In pe Jurie with frendis in feere.

I. A pos. A! lorde, pou wote wele ilke a tyde,

be Jewes pei layte be ferre and nere,

To stone pe vnto dede,

Or putte to pereles payne; -

And pou to pat same stede

Covaites to gange agayne.

Jesus. 3e wote by cours wele for to kast, be daie is now of XII oures lange, And whilis light of pe day may last It is gode pat we grathely gange.

For whan daylight is pleynly past,

Full sone pan may ze wende all wrang;

And to zou saie I more,

How pat Lazar oure frende

Slepes nowe, and I therfore

With zou to hym will wende.

II. A pos. We will be ruled aftir pi rede,

But and he slepe he schall be saue.

Jesus. I saie to zou all, Lazare is dede,

And for zoll, grete joie I haue.

je wote $i$ was noght in pat stede;

'Therfore go we togedir.

I. Apos. Go we and dye with hym pore

ist eine teils mehr, teils weniger freie widergabe von Joh. XI, 7-12, 14-16:

Eamus in Judaeam iterum.

Dicunt ei discipuli: Rabbi, nunc quaerebant to Judsei lapidare, et iterum vadis illuc?

Respondit Jesus: Nonne duodecim sunt horse diei? Si quis ambulaverit in die, non offendit, quia lucem hujus mundi videt;

Si autem ambulaverit in nocte, offendit, quia lux non est in eo.

Haec ait, et post haec dixit eis: Lazarus amicus noster dormit: sed vado nt a somno excitem eum. 
Dixerunt ergo discipuli ejus: Domine, si dormit, salvas erit.

Tunc ergo Jesus dixit eis manifeste: Lazarus mortuus est.

Et gaudeo propter vos, ut credatis, quoniam non eram ibi. Sed eamus ad eum!

Dixit ergo Thomas, qui dicitur Didymus, ad condiscipulos: Eamus et nos, ut moriamur cum eo!

Das kurze gespräch zwischen den beiden schwestern Marie und Martha in der zweiten scene dieses spiels ist unabhängig vom texte der Vulgata, aber in den worten 199, 174-185:

Fadir! pat is in henyn on highte!

I panke pe euere ouere all thyng,

That hendely heres me day \& nyght,

And takis hede vnto myn askyng:

Wherfore fouchesaffe of thy grete myght

So pat pis pepall, olde and zyng,

That standis and bidis to se pat sight,

May trulye trowe and haue knowyng,

This tyme here or I pas

How pat pou has me sent.

Lazar, veni foras,

Come fro thy monument,

die Christus unmittelbar vor und bei der auferstehung des Lazarus spricht, ist widerum eine anlehnung an Joh. XI, 41-43:

Patorl gratias ago tibi, quoniam audisti me.

Ego autem sciebsm, quis semper me audis, sed propter populum, qui circumstat, dixi: ut credant, quis tu me misisti.

Haec cum dixisset, voce magna clamavit: Lazare, veni foras!

nicht zu verkennen. Gegen den bericht des evangelisten, aber der situation des sttuckes entsprechend, richtet der eben aus dem grabe herausgetretene Lazarus worte der verehrnng an Christus und fordert das umherstehende volk auf, die lehren des herrn zu beachten und nach ihnen zu leben (199, 186-197).

In dem folgenden myster (The entry into Jerusalem upon the Ass) sind wir nicht im stande eine einheitliche quelle nachzuweisen, da uns hier entlehnungen ans drei evangelien entgegentreten. In der ersten partie des sttlckes ist der dichter der darstellung des Mattheus-evangelinms gefolgt. Die verse 201, 15-202, 28:

Vnto jone castell pat is zou agryne,

Gois with gud harte, and tarie nozt,

My comaundement to do be ze bayne.

Also I zou charge loke it be wrought, bat schal ze fynde 
An asse, pis feste als ze had soght,

.3e hir vubynde

With hir foole, and to me hem bring,

lat I on hir may sitte a space;

So pe prophicy clere menyng

May be fulfilled here in pis place,

'Doghtyr Syon,

Loo! pi lorde comys rydand on an asse

be to opon'

klingen stark an Matth. XXI, 2, 4-5:

Ite in castellum, quod contra vos est, et statim invenietis, asinam alligatam, et pullum cum ea: solvite, et adducite mihi.

Hoc autem totum factum est, ut adimpleretur quod dictum est per Prophetam, dicentem:

Dicite filiae Sion: Ecce rex tuus venit tibi mansuetus, sedens super asinam

an und ebenso 202, 29-30:

Yf any man will zou gaynesaye,

Say pat youre lorde has nede of pam

an Matth. XXI, 3:

Et si quis vobis aliquid dixerit, dicite quia Dominus his opus habet. Zu dem abschnitte von der heilung des blinden durch Christus gibt die herausgeberin Matth. XX und Marc. $X$ als vorlagen an. Wir glauben jedoch, dass der dichter hierbei nur dem Marc.evangelium gefolgt ist, weil hier, wie bei Marc., nur ein blinder den herrn um heilung seines ubels anfleht, während nach der darstellung bei Matth. zwei ungltickliche um hilfe bitten. Eine ubereinstimmung unseres und des biblischen textes zeigt sich. in den versen $211,321-322$ :

Jesu! pe son of dauid calde.

Marc. X, 47:

bou haue nercy:

Jesus filii David, miserere mei.

Frl. Smith vermutet, dass der verfasser die partie 212, 358-213, 391, in welcher die heilung eines lahmen dargestellt wird, auf das Joh. V, 5-14 herichtete wunder Jesu von der heilung eines kranken gegründet habe. Nach unserer ansicht jedoch ist dieser teil des uns vorliegenden spiels eine durchaus freie erfindung des dichters, $\mathrm{da}$ in beiden darstellangen die einzelheiten gänzlich von einander abweichen und auch sonst keinerlei beziehungen zwischen unserem texte und jenem abschnitte der Vulgata aufzufinden sind. Das sujet zu der folgenden scene zwischen Christus und dem obersten der zöllner, 

Si non lavero te, non habebis partem mecum.

Dicit ei Simon Petrus: Domine, non tantum pedes meos, sed et manus, et caput.

und die verse $235,57-59$ :

Petir, pou wotiste nozt zitt

What pis werke will bemene.

zu Joh. XIII, 7:

Here aftir schall pou witte

Quod ego facio, tu nescis modo, scies autem postea.

Ebenso ist eine gewisse, wenn auch nicht sehr starke anlehnung von $235,61-65$ :

3oure lorde and maistir ze me call,

And so I am, all welthe to welde,

Here haue I knelid vnto zou all,

To wasshe youre feete as ze haue feled.

Ensaumple of me take $z^{e}$ schall

an Joh. XIII, 13-15:

Vos vocatis me Magister, et Domine: et bene dicitis, sum enim.

$\mathrm{Si}$ ergo ego lavi pedes vestros, Dominus, et Magister: et vos debetis alter alterius lavare pedes.

Exemplum enim dedi vobis -

unverkennbar. Der im folgenden behandelte rangstreit der junger sowie die schlichtung desselben seitens des herrn durch hinweisung auf ein kind $(235,73-236,88)$ kann auf grund von Marc. IX, 33-37 oder Luc. IX, 46-48 aufgenommen worden sein, da bei beiden evangelisten diese episode fast ubereinstimmend berichtet wird. Welche von beiden versionen aber der dichter bei abfassung dieser partie benutzt hat, wagen wir aus mangel an direkten entlehnungen aus der einen oder der andern nicht zu entscheiden. Frl. Smith hält Marc. IX fur die vorlage, ob aber mit recht, wollen wir dahingestellt sein lassen. Nach dem verse 236, 89 zeigt dieses spiel eine grössere ltheke, in welcher, wie die darauf folgenden, aus Joh. XIII hertlbergenommenen worte 236,90 :

Quod facis fac cicius

vermuten lassen, jedenfalls das mahl Christi mit den jungern dargestellt und Judas als verräter bezichtigt worden sein wird (wahrscheinlich auf grund von Joh. XIII, 21-27).

Die verse 237, 118-123:

The fende is wrothe with zou and me,

And will zou marre if pat he may.

But Petir I haue prayed for pe,

So pat pou schall nozt drede his dray; 
And comforte pou pis meyne

And wisse hem, whan I am gone away

sind eine etwas freie widergabe des nur bei Luc. XXII, 31-32 . therlieferten ausspruchs des herrn:

Simon, Simon ecce Satanas expetivit nos, ut cribaret sicut triticum.

Ego autem rogavi pro te ut non deficiat fides tua: et tu aliquando conversus, confirma fratres tuos.

Die antwort Christi auf die worte des Petrus 237, 132, 134-135:

Petir, I saie to pe pis sawe,

bis ilke nyght or pe cokkys crowe,

Shall pou thre tymes my name denye

stimmt von den vier verschiedenen uberlieferungen der evangelisten dem wortlaute nach noch am meisten mit Matth. XXVI, 34 therein:

Amen dico tibi, quia in hac nocte antequam gallus cantet, ter me negabis

während uns in den versen $238,152,156-159,162-163$ :

3e haue bene bowne my bale to bete -

The kyngdome of heuen I you behete,

Euen as my fadir has highte itt me;

With gostely mete pere schall we mete,

And on twelffe seeges sitte schall $z \theta$,

There shall $z \theta$ sitte bedeme

XII kyndis of Israell

eine freie umschreibung von Luc. XXII, 28-30 entgegentritt:

Vos autem estis, qui permansistis mecum in tentationibus meis:

Et ego dispono vobis sicut disposuit mihi Pater regnum,

Ut edatis, et bibatis super mensam meam in regno meo, et sedeatis super thronus judicantes duodecim tribus Israel.

Das XXVIII. myster (The Agony and the Betrayal) ist eine kompilation aus allen vier evangelien. In der ersten scene fusst der dichter hauptsăchlich anf Matth. (XXVI, 36-56) und Marc. (XIV, 27-50), bei welchen die leiden Christi im garten Gethsemane am ausfuhrlichsten berichtet werden, während or sich in der dritten, in welcher die gefangennahme des heilands behandelt wird, entschieden an die darstellungen von Joh. (XVIII, 4-13) und Luc. (XXII, 48-54) anlehnt. Eigene erfindung unseres antors ist nur die ausfthrung des zweiten anftritts, der eine versammlung der Juden im palaste des hohen priesters zum gegenstande hat.

Auch das nächste spiel (Peter denies Jesus. Jesus examined by Caiaphas) zeigt, wie therhạupt die meisten sttlcke, welche Christi 
verurteilung behandeln, eine völlige vermischung der biblischen tuberlieferungen (Matth. XXVI, 57-75, Marc. XIV, 53-72, Luc. XXII, 54-71, Joh. XVIII, 12-27). Frl. Smith gibt fur scene 2, in der Petrus seinen herrn dreimal verleugnet, Matth. XXVI, 69-71 als vorlage an; mit ebendemselben rechte könnte aber auch Luc. XXII, 56-60 und Mare. XIV, 67-71 herbeigezogen werden, da bei diesen drei evangelisten der bericht tuber jene episode aus der leidensgeschichte des heilands fast vollständig tubereinstimmt. Antibiblisch ist in dem uns vorliegenden und den folgenden stlicken die verklagung Christi durch die häscher ('milites'), ein zug, der sich auch in den entsprechenden spielen der drei ubrigen englischen mysteriensammlungen durchaus verfolgen lässt.

Spiel XXX (The Dream of Pilate's Wife: Jesus before Pilale) beruht seinem inhalte nach im wesentlichen auf dem pseudoevang. Nicod. (Gesta Pilati) I-II und zum teil auf Luc. XXIII, 1-7; eigene erfindung des dichters aber sind die gespräche des Pilatus mit seiner gemahlin Percula und seinem sohne, sowie die scene im schlafzimmer des landpflegers. Die vorlagen sind in diesem stlicke mit solchem geschick verarbeitet, dass sich nur noch in den versen 284, 346, 349-350:

Pil. Nowe gode sir, be pi feith, What is Osanna to saie?

Bed. It is als moche to me for to meve, (Youre prelatis in pis place can it preue), Als, 'oure Sauiour and souerayne, bou saue vs, we praye'

eine gewisse anlehnung an den wortlant von evang. Nicod. I:

Dixit eis Pilatus 0sanna in excelsis quo modo interpretatur? Dicunt ei: Salva nos qui es in exeolsis.

erkennen lässt; aber wie bei all' den gerichtsscenen unserer sammlung, wird auch in diesem myster der stoff der quellen ungebuhrlich in die breite gezogen. Die dem landpfleger Pilatus in den mund gelegte erklïrung seines namens $271,13-14$, 17-18:

And my modir hight Pila pat proude was o pight,

0 Pila pat prowde and Atus hir fadir he hight.

For pus schortely I haue schewid you in sight,

Howe I am prowdely prewed Pilatus

ist vom dichter einer im mittelalter jedenfalls ziemlich verbreitet gewesenen legende tiber diesen statthalter entlehnt worden. In 
dem XXIV. sttlcke (Processus Talentorum) der Towneleysammlung wird die abstammung des Pilatus nach einer anderen version ' der sage berichtet, indem hier letzterer als sohn des königs Athus und der Pila bezeichnet wird; es heisst daselbst: Stemmate regali kyng Athus gate me of Pila.

Spiel XXXI (Trial before Herod) ist eine weitschweifige, ganz im sinne des vorigen mysters gehaltene gerichtsscene. . Ausser einigen aussprtichen and wundern Christi (speisung der 5000 menschen, auferweckung des Lazarus), welche in form von anklagen gegen letzteren vorgebracht werden, enthält dieses lange sttlek keinerlei entlehnungen aus der Vulgata oder den pseudo-evangelien.

Das nächste myster (Second accusation before Pilate: remorse of Judas, and purchase of Field of Blood) bernht im allgemeinen auf Lac. XXIII, 13-14 und Matth. XXVII, 1-10, zeigt aber anch, wie das vorhergehende, eine menge selbständig vom dichter eingefuhrter ztige. Die form ist hier widerum so frei behandelt worden, dass wir nur in den versen $312,158-162$ :

Judas. Sir, I haue synned full grenously, Betraied pat rightwisse bloode, Jesus And maistir myne.

Kaiph. Bewscher, what is pat till vs, be perill and pe plight is thyne

eine anlehnung an Matth. XXVII, 4:

Peccavi, tradens sanguinem justum. At illi dixerunt: Quid ad nos? to videris

und in $317,325-326,329$ :

Pilat. Sir, it schall not combre $\nabla 8$, Nor come in oure Corbonan.

Kaiph. It is price of bloode pat we with it boght eine solche an Matth. XXVII, 6:

Non licet e0s mittere in corbonam: quis pretium sanguinis est zu erkennen vermøgen. Die eben angefthrten verse, in denen Pilatus als Römer und heide von 'oure Corbonan' spricht, können zeigen, wie der dichter oft ohne jede tuberlegung die biblischen worte den personen seiner sttlcke zuteilt.

In dem ersten teile (s. 320-325) von spiel XXXIII (The second Trial before Pilate continued; the Judgment of Jesus) hat

1 Diese gestalt der sage war nach Creizenach, Legenden und Sagen von Pilatus (Beitrïge z. Gesch. d. dentschen Spr. u. Lit, hrsg. von Paul und Braune, I, 89 fi.) die allgemein verbreitete. 
der dichter seiner darstellung Matth. XXVII, 15-17, 21-31 und Joh. XIX, 1-16 zu grunde gelegt und hat sich hierbei von jedweder wörtlichen entlehnung frei gehalten. Beinahe den dritten teil dieses mysters (s. 325-329) bildet die weitschweifige ausftihrung des im pseudo-evang. Nicod. I enthaltenen zuges, dass sich die banner der Juden vor dem in die gerichtsstätte eintretenden Christus bis zur erde geneigt haben sollen. In dem letzten abschnitte, in welchem die schliessliche verurteilung des herrn durch Pilatus behandelt wird, folgt der verfasser im allgemeinen wider dem berichte der beiden oben erwähnten evangelisten; es werden hier aber, wol den darstellern zu liebe, noch zahlreiche martern und grausamkeiten an dem erlöser vertbt, von denen wir in der Vulgata nichts erfahren.

Spiel XXXIV (Christ led up to Calvary) ist eines der wenigen stticke ther die leidensgeschichte Christi, die nur anf eine quelle zurtickgehen; die vorlage ist hier Luc. XXIII, 26-33. Die erste scene, in der sich die drei 'milites' (henkersknechte) auf die kreuzigung des heilandes vorbereiten, ist durchaus freie erfindung des dichters, aber in den versen $342,161-343,176$ :
Doughteres of Jerusalem cytte,
Sees, and mournes no more for me,
But thynkes vppon this thyng;
For youre selfe mourne schall $z^{\theta e}$,
And for pe sonnes pat borne schal be
of yowe, bothe olde and yonge;
For such fare schall befalle,
That ze schall giffe blissyng
To barayne bodies all,
That no barnes forthe may brynge.
For certis ze schall see suche a day,
'That with sore sighlyng schall ze saye
Vnto pe hillis on highte,
'Falle on vs, mountaynes, and ze may,
And conere vs fro pat felle affraye,
'That on vs sone schall light'

aus dem zweiten auftritte ist eine engere anlehnung an Luc. XXIII, 28-30 unverkennbar:

Filiae Jerusalem, nolite flere super me, sed super vos ipsas fleto, et super filios vestros.

Quoniam ecce venient dies, in quibus dicent: Beatae steriles, et ventres, qui non genuerunt, et ubera, quae non lactaverunt.

Tunc incipient dicere montibus: Cadite super nos! et collibus: Operite nos! 

lieferung der Vulgata legt der autor dem gekreuzigten Christus die worte $365,192-195$ :

For foxis per dennys haue pei, Birdis hase ther nestis to paye, But pe sone of man this daye, Hase nozt on his heed for to reste

in den mund, welche letzterer in einer ganz anderen situation gegen einen schriftgelehrten geäussert hatte; die diesen versen zu grunde gelegte stelle, Matth. VIII, 20, lautet:

Vulpes foreas habent, et volucres coeli nidos; Filius antem hominis non habet, ubi caput reclinet.

In dem gespräche der beiden mit Christus gekreuzigten schächer $365,196-212$ :

Lat. a sin. If pou be Goddis sone so free, Why hyng pou pus on pis hille?

To saffe nowe pi selffe late $v s$ see, And vs now, pat spedis for to spille.

Lat. a dex. Manne, stynte of thy steuen and be stille, For douteles thy God dredis pou nozt,

Full wele are we worthy thertill,

Vnwisely wrange haue we wrought iwisse.

Noon ille did hee,

bus for to dye;

Lord! haue mynde of me

What pou art come to pi blisse.

Jesus. For sothe, sonne, to be schall I saie,

Sen pou fro thy foly will falle,

With me schall dwelle nowe pis daye,

In paradise place principall

lehnt sich der verfasser teils mehr, teils weniger an Luc. XXIII, 39-43 an:

Si tu es Christus, salvum fac temetipsum et nos!

Respondens autem alter increpabat eum, dicens: Neque tu times Deum, quod in eadem damnatione es?

Et nos quidem juste, nam digna factis recipimus; hic vero nihil mali gessit.

Et dicebat ad Jesum: Domine, memento mei, cum veneris in regnum tuum.

Et dixit illi Jesus: Amen dico tibi: Hodie mecum eris in paradiso.

Die legende von der widererlangung der sehkraft des blinden Longeus, welche der dichter in dieses spiel anfgenommen hat (s. 368), ist ein in den geistlichen dichtungen des mittelalters 
oft behandelter stoff. 1 Die evangelien und selbst die pseudoevangelien berichten aber von dieser heilung nichts; die griechische version des ersten teils vom evang. Nicod. XI nennt nur den namen Longeus und tberträgt denselben auf den hauptmann, welcher Matth. XXVII, 54, Marc. XV, 39 und Luc. XXIII, 47 nach dem verscheiden Christi erwähnt wird. Der letzte abschnitt dieses sttlckes, Christi abnahme vom kreuze und grablegung durch Joseph von Arimathia und Nikodemus, folgt im allgemeinen der darstellung von Joh. XIX, 38-42.

Das XXXVII. myster (The Harrowing of Hell) beruht, abgesehen von einigen unbedentenden zutaten des dichters, vollständig auf einer nichtbiblischen quelle, auf der latein. version des evang. Nicod. ${ }^{2}$ (Descensus Christi ad Inferos, A) II-VIII. Da beinahe das ganze sttick reminiscenzen an den wortlaut der vorlage anfweist, so mag hier nur die erzählung Johannes des täufers herausgegriffen und zur vergleichung neben den text der apokryphen quelle gestellt werden $(376,75-82)$ :

I baptiste hym with bothe my hande

Euen in pe floode of flume Jordanne.

be holy goste fro heuene discende,

Als a white dowue doune on hym panne,

The Fadir voice, my mirthe to mende,

Was made to me euen als manne,

This is my sone, he saide,

In whome me paies full wele:

evang. Nicod. (Desc. ad Infer.) II, 3:

Et baptizari eum in flumine Jordanis, et vidi spiritum sanctum descendentem super eum in specie columbre, et andivi vocem de coelis dicentem Hic est filins meus dilectus, in quo bene complacui.

Bisher sind uns lateinische citate nur aus der Vulgata begegnet; hier erscheinen zam ersten male solche aus einer apokryphen schrift. Die verse $379,121,123$ :

Attollite portas principes,

Et eleuamini eternales

and $382,181,183$ :

Principes, portas tollite,

Et introibit rex glorie

gehen auf das evang. Nicod. (Desc. ad Infer.) V, 1 zurtick:

Tollite portas principes vestras, et elevamini portae aeternales, et introibit rex gloriae.

1 Vgl. Ch. P. vol. II, s. 6 i.

2 Bei Tischendorf 8. 369-395. 
Das einzige biblische citat in diesem stucke, $393,374-375$ :

Ne derelinquas, domine

Animam meam [in] inferno,

ist mit nur geringer abänderung psalm XV, 10:

Quoniam non derelinques animam meam in inferno entlehnt.

Das nächste stlick (The Resurrection; fright of the Jens) ist eine freie, weitschweifige bearbeitung von Matth. XXVII, $45,51-54,61-66$ und XXVIII, 1-15; nur die von einem centurio abgegebene erklärung der bei dem tode des erlösers eingetretenen finsterniss 401, 99-100:

3e wote oure clerkis pe clipsis pei call

Such sodayne sight

zeigt beziehung zum evang. Nicod. (Gesta Pilati) XI: tudinem.

Qui dixerunt praesidi Eclipsis solis facta est secundum consueAllerdings ist in dieser stelle die situation eine andere als in dem uns vorliegenden spiele; hier dringen die Juden dem landpfleger Pilatus diese erklärung auf, während in unserem stlick der letztere dieses phänomen als etwas naturgemässes, den gelehrten völlig bekanntes darzulegen sucht.

Spiel XXXIX (Jesus appears to Mary Magdalene after the Resurrection) geht auf Joh. XX, 11-18 zurtick. Schwache, aber doch immerhin unverkennbare anlehnung an den wortlaut der biblischen vorlage zeigen die verse $422,23,26,38-41$ :

Jesus. Why wepis pou soo als pou wolde wede, Whome sekist pou pis longe daye?

Maria. Swete Sir, yf pou hym bare awaye, Saie me pe sothe and thedir me leede, Where pou hym didde withonten delay

Joh. XX, 15: I schall hym seke agayne, goode speede:

Dixit ei Jesus: Mulier, quid ploras? quem quaeris? Illa existimans, quia hortulanus esset, dixit ei: Domine! si tu sustulisti eum, dicito mihi, ubi posuisti eum; et ego eum tollam,

sowie $424,82-85$ :

Negh me noght, my loue, latte be!

Marie, my doughtir swete.

To my fadir in Trinite

Joh. XX, 17:

Forpe I stigh nozt yette:

Noli me tangere, nondum enim ascendi ad Patrem meum. 
Das sujet des nächsten mysters ist die bei Luc. (XXIV, 13-33) ansfubrlich und bei Marc. (XVI, 12-13) nar kurz berichtete erzählung von dem zusammentreffen Christi mit zwei nach Emmaus ziehenden jungern. Unser dichter folgt der darstellung des zuerst genannten evangelisten und zeigt besonders in den versen $428,67-69$ :

What are pes meruailes pat ze of mene,

And pus mekill mournyng in mynde pat ze make,

Walkyng pus wille by pes wayes?

engere anlebnung an kap. XXIV, 17:

Qui sunt hi sermones, quos confertis ad invicem ambulantes, et estis tristes?

und in $428,70-72$ :

Why arte pou a pilgryme, and haste bene

At Jerusalem, and haste pou noght sene

What dole has ben done in pes daies?

eine solche an kap. XXIV, 18:

Tu solus peregrinus es in Jerusalem, et non cognovisti, quae facts sunt in illa his diebus?

Spiel XLI (The Purification of Mary: Simeon and Anna prophesy) bernht in den beiden ersten scenen, in denen sich ein presbyter, die prophetin Hanna und Simeon in langen monologen tuber das erscheinen des heilandes ergehen, auf freier erfindung des dichters und in den folgenden auftritten im allgemeinen auf Lac. II, 22-38. Der text der Vulgata ist sehr selbständig behandelt und ist nur noch in Simeon's dankesworten gegen das Christuskind widerzuerkennen 446,415-423:

In peace lorde, nowe leyf thy servand,

For myne eys haith seyn that is ordand,

The helth for all men that be levand, here for ay.

Thath helth lorde hais thowe ordand, I say,

Here before the face of thy people,

And thy light hais thowe shynyd this day, for evermore

Luc. II, 29-32:

To be knowe of thy folke that was febyll:

Nunc dimittis servum tuum, Dominel secundum verbum tuum in pace; quis viderunt oculi mei salutare tuum, quod parsati ante faciem omnium populorum; lumen ad revelationem gentium, et gloriam plebis tuae Israel,

wennschon anch hiermit die thereinstimmung nur sehr gering ist. Die lobpreisungen des alten Simeon sind zum teil in einem 
recht ubberschwänglichen stile, ähnlich dem des Cant. cant. gehalten; aber ausser den mannigfachen bezeichnungen Christi als rose, blume etc. findet sich keine beziehung zu jenem alttestamentlichen liebesgesange.

Nach der ansicht von frl. Smith beruht das ganze folgende spiel (The Incredulity of Thomas) auf Joh. XX, 19-29. Fur die verse 85-198 stimmen wir dieser angabe vollkommen bei, uicht aber für die erste partie (v. 1-84), da hier mehrere zuge aus Luc. XXIV aufgenommen sind, welche sich im Joh.-evangelium nicht finden. Den worten des plötzlich unter die versammelten apostel tretenden herrn $449,44-45 ; 450,50-51,57-59$ :

What mournyng in youre hertis is brought?

I ame Criste, ne drede zou noght.

Behalde and se myn handis and feete, And grathely gropes my woundes wete.

And se, pat I baue flessh and bone, Gropes me nowe.

For so ne has sperite none

ist eine anlehnung an Luc. XXIV, 38-39:

Quid turbati estis, et cogitationes ascendunt in corda vestra?

Videte manus meas, et pedes, quia ego ipse sum; palpate, et videte! quia spiritus carnem et ossa non habet, sicut me videtis habere

nicht abzusprechen. Auch der folgende abschnitt (450,61 bis 451, 84), in welchem Christus von den erschrockenen jungern speise verlangt, um dieselben zu uberzeugen, dass er wirklich ihr meister, nicht bloss dessen geist sei, kann nur auf grund von Luc. XXIV, 41-43 in die darstellung aufgenommen worden sein, da jene erzählung nur bei diesem evangelisten berichtet wird. Die verse $451,89-90,93-96$ :

And vnto zou pe holy goste

Releffe yow here.

Whome pat ze bynde bounden schall be

Right at youre stenene,

And whome pat ze lesid losed schalbe

Euer more in heuene

klingen stark an Joh. XX, 22-23 an:

Accipite Spiritum sanctum!

Quorum remiseritis peccata, remittuntur eis; et quorum retinueritis, retenta sunt;

und ebenso entspricht 452,$129 ; 453,158-154,163$ :

Petrus. Jesu oure lorde pan haue we sene.

Thomas. Till pat I see his body bare, 
And sithen my fyngir putte in thare within his hyde,

And fele the wound pe spere did schere rizt in his syde;

Are schalle I trowe no tales betwene

im allgemeinen Joh. XX, 25:

Dixerunt ergo ei alii discipuli: Vidimus Dominum! Ille (sc. Thomas) autem dixit eis: Nisi videro in manibus ejus fixuram clavorum, et mittam digitum meum in locum clavorum, et mittam manum meam in latus ejus, non credam.

Die verse $454,171-172,176,179-180$ :

Putte forthe thy fingir to me nowe, myn handis pou see;

Here in my side putte in pi hande, And be no more so mistrowand, But trowe trewly

sind beinahe wörtlich aus Joh. XX, 27:

Infer digitum tuum huc, et vide manus meas; et affer manum tuam et mitte in latus meum; et noli esse incredulus, sed fidelis tibertragen worden.

Das XLIII. stuck (The Ascension) basiert seinem inhalt nach anf Act. I, 4-14; ausserdem klingt eine anzahl von stellen in der ansprache des herrn an die apostel an Joh. XVI und XVII an; diese partien sind $457,34-36$ :

In erthe pi bidding haue I done, And clarified pe name of pe, To thy selffe clarifie pe sone:

Job. XVII, 4-5:

Ego te clarificavi super terram; opus consumavi, quod dedisti mihi, ut faciam; - et nunc clarifica me, Pater! apud temetipsum; ferner $458,61-62$ :

Fro pe worlde to take pem pray I noght

But pat pou kepe pame ay fro ill:

Joh. XVII, 15:

Non rogo, nt tollas eos de mundo, sed ut serves eos a malo, sodann 458, 73-75:

bou halowe pame, falir, forthy,

In sothfastnes so pat pei may

Be ane as we ar, yowe and I:

Joh. XVII, 17, 21:

Sanctifica eos in veritate.

Ut omnes unum sint, sicut tu Pater in me, et ego in te und schliesslich 461, 166-170: 
- pat I hense wende, als nedful is.

And butte I wende, comes noght to yowe

be comfortoure of comforteles;

And if I wende, ze schall fynde howe

I schall hym sende, of my goodnesse:

Joh. XVI, 7 :

Expedit vobis, ut ego vadam; si enim non abiero, Paracletus. non veniet ad vos; si autem abiero, mittam eum ad vos.

Die verkiindigung der einstigen widerkehr des zum himmel aufgefahrenen heilands durch den ersten engel 463, 219-223:

כe men of pe lande of Galile,

What wondir ze to hellene lokand?

bis Jesus whome ze fro youe see

Vppetane, ze schall well vndirstande,

Right so agayne come doune schall he

ist vom dichter fast wörtlich aus Act. I, 11:

Viri Galilaei, quid statis aspicientes in coelum? hic Jesus, qui assumptus est a vobis in coelum, sic veniet, quemadmodum vidistis eum euntem in coelum

thbertragen worden.

Spiel XLIV behandelt die Act. II berichtete ausgiessung des heiligen geistes und zeichnet sich vor den ubrigen mysterien durch eine grössere anzahl lat. citate aus. Das erste, s. 465:

Nobis precepit dominus predicare populo et testificare quia prope est iudex viuorum et mortuorum ist mit geringer abänderung Act. X, 42:

Et praecepit nobis praedicare populo et testificari, quia ipse est, qui constitutus est a Deo judex vinorum et mortuorum entnommen. Die für das der lateinischen sprache nicht mächtige volk berechnete umschreibung oder erklärung dieses citats lautet 466, 13-16:

Oure lord comaunded vs, more and lesse,

To rewle vs right aftir his rede,

IIe badde vs preche and bere wittenesse

'That he schulde deme both quike and dede.

$466,35-36$ :

Cum venerit paraclitus

Docebit vos omnia

ist eine verquickung von Joh. XV, 26:

Cum autem venerit Paracletus, quem ego mittam vobis a Patre, spiritum veritatis, qui a Patre procedit, ille testimonium perhibebit de me und Joh. XIV, 26:

Paracletus autem Spiritus sanctus, quem mittet Pater in nomine meo, ille vos docebit omnia. 
In den von engeln gesungenen versen 469, 137-138:

\section{Veni creator spiritus,} mente tuorum visita,

welche der erste apostel durch die worte 469, 135-136:

bei praied pe spirite come till vs,

And mende oure myndis with mirthis ma

in die landessprache uberträgt, erkennen wir den anfang jenes berühmten pfingsthymnus, der nach Kurtz ${ }^{1}$ von Karl d. Gr. verfasst worden sein soll. Die worte des dritten apostels 470, 147:

Tristicia impleuit cor vestrum

sind aus Joh. XVI, 6:

Sed quia haec locutus sum vobis, tristitia impleuit cor vestrum und 470, 149:

aus Joh. XVI, 20:

Sed conuertetur in gaudium

Vos autem contristabimini, sed tristitia vestra vertetur in gaudium entlehnt. Petrus' ansprache an die versammelten Juden 471, 181-192, in welcher auf die weissagung des propheten Joel (II, 28) tuber die ausgiessung des geistes hingedeutet wird, klingt sehr stark an Act. II, 14-16 an; die prophezeiung selbst:

Et erit in nouissimus diebus, dicit dominus, effundam de spiritu meo super omnem carnem

gibt, abgesehen von der falschen form nouissimus für nouissimis, wort fur wort Act. II, 17 wider.

Das nächste myster (The Death of Mary) ist anf die fassung B des Transitus Mariae ${ }^{2}$ gegrtundet; der apokryphe stoff ist vom verfasser durchaus frei behandelt worden, so dass wir keinerlei anlehnungen an den wortlaut der vorlage nachweisen können.

Spiel XLVI (The Appecirance of our Lady to Thomas) beruht ebenfalls auf dem Transitus Mariae, aber auf der fassung A (s. 119-121), da nur diese die vision des apostels Thomas enthält. Zu dem lobgesange der engél $483,105-484,117$, einer freien umschreibung des uns noch erhaltenen, mit noten versehenen, lateinischen textes:

Surge proxima mea colnmba mea tabernaculum glorie vasculum vite templum celeste

1 Kurtz, Lehrbuch der Kirchengeschichte I, § 82, 2, s. 65. s. $125-130$.

2 Apocalypses Apocryphae, herausg. von Tischendorf, Lipsiae 1866, 
haben wir eine hestimmte quelle nicht finden können. Vielleicht haben wir hier eine vermischung von Cant. cant. II, 10: Surge, propera, amica mea! columba mea! fornosa mea! et veni und Transitus Mariae B s. 135:

Exsurge amica mea et proxima mea vor uns; einleuchtender erscheint uns indessen die ansicht der herausgeberin, dass wir in den worten:

$$
\begin{aligned}
& \text { tabernaculum glorie, } \\
& \text { vasculum vite, } \\
& \text { templum celeste - }
\end{aligned}
$$

den rest einer lateinischen sequenz zu erkennen haben. Der text $\mathrm{zu}$ dem folgenden gesange der engel s. 484:

Veni de libano sponsa veni coronaberis,

zu welchem uns ebenfalls die noten erhalten sind, ist dem Cant. cant. IV, 8:

Veni de Libano, sponsa mea! veni de Libano, veni! coronaberis de capite Amana etc.

entnommen. Für die worte s. 487:

Veni electa mea et ponam in te tronum meum

Quia concupiuit rex speciem tuam,

welche dem engelsgesange am ende der vision zu grunde gelegt sind, sind wir jedoch widerum nicht stande gewesen, die quelle nachzuweisen. Frl. Smith fuhrt in ihren anmerkungen iiber die musik in unserer sammlung s. 527 eine anzahl von beispielen auf, in welchen derselbe text namentlich im Marienkultus den responsorien zu grunde gelegt worden ist.

Das aus drei scenen bestehende XLVII, stlick behandelt die in der version B des Transitus Mariae s. 135-136 berichtete himmelfahrt und krönung der heiligen jungfrau. Wie in dem myster wher den tod der mutter Gottes, so sind auch in diesem keine wörtlichen entlehnungen aus der vorlage zu verzeichnen.

Im letzten stllcke unserer sammlung (The Judgment Day) gibt Gott vater in einem langen monologe einen uberblick uber sein walten und wirken vom anbeginn der welt bis zum hereinbrechenden gerichte. Von 503, 177 an sind die vom dichter oder vielleicht bloss vom abschreiber Gott zugeteilten worte als solche von Christus zu betrachten, da in dieser partie öfters wendungen wie mi fadir $(503,178)$, mi postelis $(504,185)$ begegnen. Dieses myster zeigt widerum mehrfache anlehnungen an den text der Vulgata; zunächst in dem an Adam gerich- 
teten verbote Gottes, den baum der erkenntniss zu meiden, 497, 14-15:

I saide, 'what tyme pou etis of pis, Manne, pou spedes pi selue to spill':

Gen. II, 17:

In quocumque enim die comederis ex eo, morte morieris.

Ebenso lehnen sich die verse 499,62-80 unverkennbar an Matth. XXV, 31-33 und 508, 285-512, 356 an Matth. XXV, $35-44$ an.

Fassen wir das ergebniss unserer ausfuhrungen kurz zusammen, so müssen wir gestehen, dass der dichter bei abfassung der uns vorliegenden mysterien vielfach unselbständig verfahren ist. Ziehen wir aber in betracht, dass diese spiele trotz ihrer damals schon seit längerer zeit erfolgten loslösung von der kirche ausser der ergötzung des publikums immerhin auch noch den zweck hatten, dem mit der lateinischen sprache nicht vertrauten volke den inhalt der heiligen schrift zu eröffnen, so düfen wir dem verfasser keinen zu grossen vorwurf daraus machen, wenn er seine vorlagen bisweilen zu wenig selbständig behandelt und sich hier und da sklavisch an den text derselben gehalten hat; war er ja in vielen fällen, wie in den verheissungen Gottes und den aussprüchen Christi, geradezu gezwungen, sich der worte der heiligen schrift zu bedienen, wenn er anders den zuhörern und der kirche gegentiber nicht als falscher interpret der biblischen geschichte gelten wollte. Erwägen wir ferner, dass sich damals das englische drama in seiner ersten entwickelungsphase befand, dass unserem dichter vielleicht gar keine oder nur ganz unbedeutende muster fur seine spiele vorlagen, so ist ihm ein gewisser grad von originalität nicht abzusprechen. Er schrieb diese stïcke im geiste seiner zeit und hat mit ihnen, wie die mehrere jahrhunderte hindurch immer widerkehrenden auffuhrungen derselben gezeigt haben, den geschmack seiner landsleute durchaus getroffen.

LEIPZIG.

P. KAMANN. 